\title{
Epigenetic dynamics during preimplantation development
}

\author{
Chelsea Marcho*, Wei Cui ${ }^{*}$ and Jesse Mager \\ Department of Veterinary and Animal Science, University of Massachusetts Amherst, 661 North Pleasant Street, \\ Amherst, Massachusetts 01003, USA
}

Correspondence should be addressed to J Mager; Email: jmager@vasci.umass.edu

${ }^{*}$ (C Marcho and W Cui contributed equally to this work)

\begin{abstract}
Successful mammalian development requires descendants of single-cell zygotes to differentiate into diverse cell types even though they contain the same genetic material. Preimplantation dynamics are first driven by the necessity of reprogramming haploid parental epigenomes to reach a totipotent state. This process requires extensive erasure of epigenetic marks shortly after fertilization. During the few short days after formation of the zygote, epigenetic programs are established and are essential for the first lineage decisions and differentiation. Here we review the current understanding of DNA methylation and histone modification dynamics responsible for these early changes during mammalian preimplantation development. In particular, we highlight insights that have been gained through next-generation sequencing technologies comparing human embryos to other models as well as the recent discoveries of active DNA demethylation mechanisms at play during preimplantation.

Reproduction (2015) 150 R109-R120
\end{abstract}

\section{From zygote to blastocyst}

Mammalian preimplantation development is a time of dynamic change in which the fertilized egg undergoes cleavage divisions developing into a morula and then a blastocyst with the first two distinct cell lineages (inner cell mass (ICM) and trophectoderm (TE)). This developmental period is characterized by three major transitions, each of which entails pronounced changes in the pattern of gene expression. The first transition is the maternal-to-zygotic transition (MZT), which serves three functions: i) to destroy oocyte-specific transcripts (e.g., H1oo (Tanaka et al. 2001)), ii) to replace maternal transcripts that are common to the oocyte and early embryo with zygotic transcripts and iii) to facilitate the reprogramming of the early embryo by generating novel transcripts that are not expressed in the oocyte (Latham et al. 1991). In mice, zygotic gene activation initiates during the 1-cell stage, and is clearly evident by the 2-cell stage (Latham et al. 1991, Schultz et al. 1993). Coincident with genome activation is the implementation of a chromatin-based transcriptionally-repressive state (Nothias et al. 1995, Schultz 2002) and more efficient use of TATA-less promoters (Majumder \& DePamphilis 1994), which are likely to play a major role in establishing the appropriate pattern of gene expression required for successful development.
The second developmental transition is compaction, which occurs during the 8-cell stage, when the first morphological differentiation occurs due to adhesive interactions between the blastomeres generating a tightly organized and less distinct mass of cells (Fleming et al. 2001). Accompanying compaction are pronounced biochemical changes through which blastomeres acquire characteristics resembling somatic cells, reflected in such features as ion transport, metabolism, cellular architecture and gene expression pattern (Fleming et al. 2001, Kidder \& Winterhager 2001). Following compaction, cleavage divisions allocate cells to the inside of the developing morula. These inner cells are set aside between the 8-cell and 16-cell stage, and then again between the 16-cell stage and the 32-cell stage (Pedersen et al. 1986). The inner cells of the morula give rise to the ICM cells from which the embryo proper is derived, whereas the outer cells differentiate exclusively into the $T E$, which gives rise to extraembryonic tissues (Yamanaka et al. 2006). The TE is a fluidtransporting epithelium that is responsible for forming the blastocoel cavity and is essential for continued development and differentiation of the ICM (Biggers et al. 1988, Watson et al. 1990). Distinct differentiation first occurs in the blastocyst and is characterized by differences in gene expression between the ICM and 
TE cells (Nichols \& Gardner 1984, Pesce \& Scholer 2001). Additionally, by the time of implantation the primitive endoderm has differentiated from the ICM/ epiblast and resides as a single-cell layer on the blastocoel cavity side of the ICM/EPI (reviewed in Schrode et al. (2013)).

These dynamic morphological, cellular and molecular events are driven by gene expression changes facilitated by epigenetic phenomenon, including DNA methylation and histone modifications at sites throughout the genome. Below we review the current understanding of the mechanisms responsible for regulation of epigenetic programming and re-programming that occur during mammalian preimplantation.

\section{DNA methylation dynamics in the preimplantation mouse embryo}

In mammalian cells, the predominant form of DNA methylation occurs at $\mathrm{CpG}$ dinucleotides. Throughout the genome, non-promoter associated $\mathrm{CpGs}$ are generally found methylated. However, the majority of protein coding genes have regions of high-density CpG dinucleotides termed $\mathrm{CpG}$ islands. In most cell types the methylation status at these promoter associated $\mathrm{CpG}$ islands correlate with the transcriptional activity of the locus - actively transcribed genes generally are not methylated while silenced genes are often found to be heavily methylated in the promoter island. Additionally, there is growing evidence that $\mathrm{CpG}$ islands found outside of transcription start sites play functional roles (Saxonov et al. 2006, Illingworth et al. 2010, Maunakea et al. 2010). While DNA methylation at gene promoters is traditionally thought to act as a binary switch (methylated, silent; unmethylated, active), it appears that CpG density, not just presence of methylation alone, also contributes to regulation of expression. For example, methylation at low CpG dense promoters still allows for transcriptional activity (Fouse et al. 2008). Furthermore, there are numerous examples, particularly of non-coding RNAs, that are transcribed, although the allele is heavily methylated (Bartolomei et al. 1993, Takada et al. 2002, Sleutels et al. 2003). These examples highlight that while there are general correlations of methylation status and gene activity, individual loci vary greatly.

In mammals, the molecular machinery responsible for adding a methyl group to cytosine residues (resulting 5-methylcytosine $(5 \mathrm{mC})$ ) has been identified as a family of DNA methyltransferases (Dnmt1, Dnmt3a, Dnmt3b, and Dnmt3l). Dnmt3a and Dnmt3b are responsible for de novo methylation and play partially redundant but independently essential roles during early development. This includes methylation of repeat regions, imprinted loci, as well as genes involved in lineage decisions (Okano et al. 1999, Bourc'his et al. 2001, Kaneda et al. 2004). More specifically, Dnmt3a and Dnmt $3 \mathrm{~b}$ help to establish de novo methylation in the blastocyst, allowing global $5 \mathrm{mC}$ levels to increase to that of somatic cells following implantation (Smith et al. 2012). Dnmt3a is maternally loaded in the oocyte and is the predominate methyltransferase in the oocyte and zygote (Kaneda et al. 2004, Kato et al. 2007), whereas Dnmt3b is transcribed upon zygotic genome activation (Watanabe et al. 2002) and is the primary mediator of de novo methylation during implantation (Borgel et al. 2010). Knockout studies in mice show that each of the Dnmts is required for viability (Li et al. 1992, Okano et al. 1999), highlighting the essential nature of de novo and maintenance methylation during development.

Dnmt1 has two functional transcripts that are expressed during development - Dnmt1s is expressed in somatic cells while Dnmt1o is specifically expressed as an oocyte specific form (Rouleau et al. 1992, Gaudet et al. 1998, Mertineit et al. 1998). Unlike Dnmt3a and Dnmt3b, Dnmt1 maintains CpG methylation by recognizing hemimethylated DNA and methlyating the unmethlyated strand, ensuring $5 \mathrm{mC}$ is maintained through DNA synthesis (Leonhardt et al. 1992, Arand et al. 2012). Targeting of Dnmt1 to replication foci occurs in most proliferating cells (Kishikawa et al. 2003, Bostick et al. 2007), however, Dnmt1o/s is largely excluded from the nucleus during early preimplantation stages (Howell et al. 2001), likely to allow for the large-scale demethylation that occurs to both haploid genomes (Figs 1 and 2).

Both sperm and oocytes contain parent- of- origin specific $5 \mathrm{mC}$ patterns. Therefore, at the time of fertilization the two haploid genomes arrive with diverse epigenomic signatures. Both parental pronuclei undergo dramatic global demethylation, presumably to ensure similar epigenetic information at the two parental alleles of the majority of genes (imprinted loci being one exception) as well as to program the newly formed zygote to a totipotent state. The male haploid genome is heavily methylated in sperm, where between 80 and $90 \%$ of all CpG dinucleotides are methylated (Mayer et al. 2000, Oswald et al. 2000, Santos et al. 2002). Global DNA methylation levels in the maternal haploid genome are approximately half that of the sperm (Howlett \& Reik 1991, Smallwood et al. 2011, Peat et al. 2014). Shortly after fertilization, the two parental genomes undergo distinct but equally dramatic waves of DNA demethylation. The paternal genome undergoes active, replication-independent demethylation within the first several hours post-fertilization. In contrast, the maternal genome largely undergoes passive, cell division-dependent diffusion of methylation, resulting in demethylation over the course of preimplantation development.

\section{Active DNA demethylation during preimplantation development by Tet3 oxidation of $5 \mathrm{mC}$}

Demethylation begins immediately in the newly formed embryo, prior to the first cell division. By the time the 


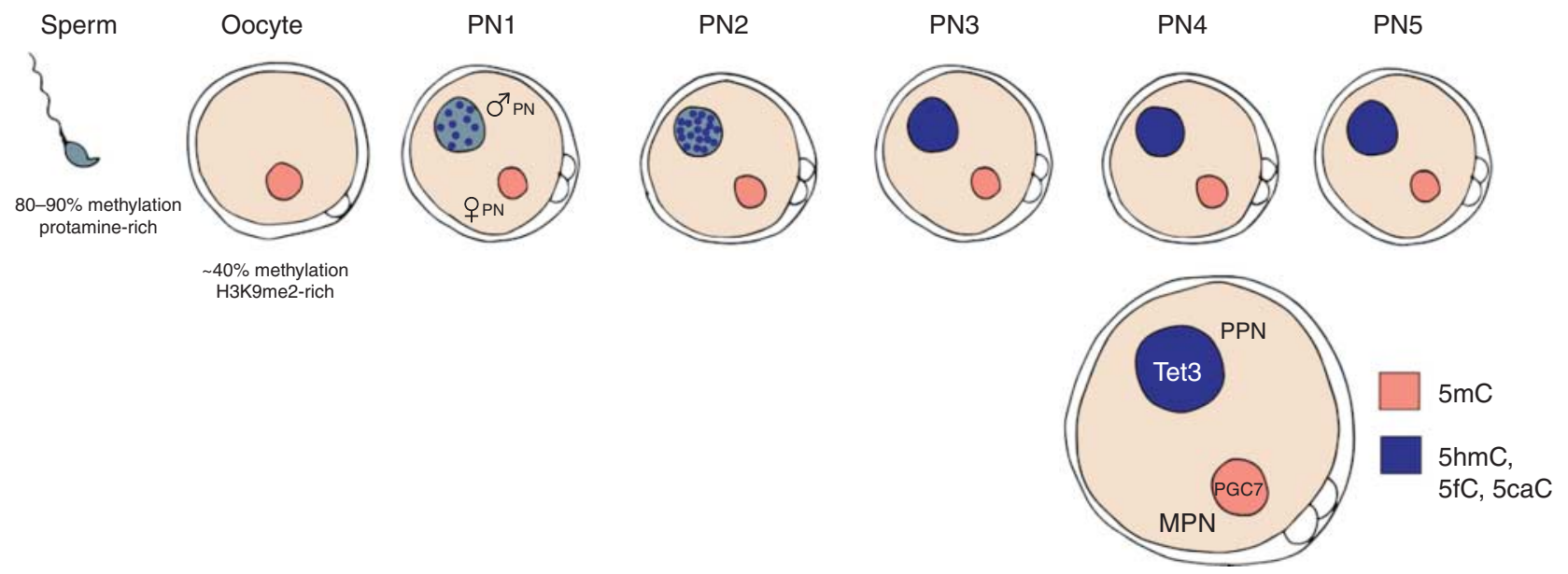

Figure 1 DNA demethylation in the zygote. Distinct demethylation dynamics occur in the maternal (pink) and paternal (blue) pronuclei prior to fusion. At fertilization, the maternal haploid genome has $\sim 40 \%$ methylation compared to nearly $90 \%$ methylation in the paternal haploid genome. Upon fertilization and continuing through pronuclear stage PN2, the paternal genome undergoes Tet3-dependent demethylation. PGC7, which preferentially binds to $\mathrm{H} 3 \mathrm{~K} 9 \mathrm{me} 2$-rich chromatin, protects the maternal genome from Tet3 activity during PN stages. By PN5 stage, the bulk of paternal $5 \mathrm{mC}$ is gone and little change has occurred to maternal methylation. PPN, paternal pronucleus; MPN, maternal pronucleus.

embryo reaches the morula stage, the genome is almost completely devoid of DNA methylation (Santos et al. 2002). Despite wide-spread global demethylation, a few regions of the genome are protected, including imprinted loci and active retrotransposons like intracisternal A particle (IAP) elements (Lane et al. 2003). The large-scale demethylation begins with the rapid, active demethylation of the paternal haploid genome.

The differences between demethylation dynamics within the maternal and paternal pronuclei are thought to arise from their distinct architecture. The paternal genome is packed mostly around protamines, which are disassembled after fertilization and re-organized with histone-containing nucleosomes (Braun 2001, Balhorn 2007). The maternal genome is largely assembled around H3K9me2-rich histones. These structural distinctions between the two haploid genomes at pronuclear stage 0 (PNO) is thought to greatly influence the timing of bulk genome-wide demethylation (Santos et al. 2005), the kinetics of which are different between the maternal and paternal pronuclei (Fig. 1). Examination of global DNA methylation by immunofluorescence showed that the paternal pronucleus undergoes division-independent demethylation (Santos et al. 2002). When the zygote reaches the PN3 stage ( $\sim 4 \mathrm{~h}$ after fertilization), there is already a dramatic loss of $5 \mathrm{mC}$ observed in the paternal pronucleus but little change in the maternal pronucleus (Mayer et al. 2000, Oswald et al. 2000). By the time of the first cell division ( $24 \mathrm{~h}$ after fertilization), there is no $5 \mathrm{mC}$ signal detected in the paternal $\mathrm{PN}$, indicating nearcomplete loss of $5 \mathrm{mC}$ methylation. Even though the two parental genomes occupy the same nucleus after PN fusion, the differences in $5 \mathrm{mC}$ levels are apparent beyond the 4-cell stage (Santos et al. 2002).

Early studies of demethylation dynamics in mice based on immunofluorescence conflicted somewhat with bisulfite DNA sequencing data sets, which did not show as dramatic a loss of $5 \mathrm{mC}$ (Oswald et al. 2000). It was not until the realization that the $5 \mathrm{mC}$ oxidation product 5-hydroxymethylcytosine $(5 \mathrm{hmC})$ is present in vivo that this discrepancy was resolved. Traditional bisulfite treatment does not distinguish between $5 \mathrm{mC}$ and $5 \mathrm{hmC}$ (Huang et al. 2010), while the antibodies used for immunofluorescence specifically (and only) detect $5 \mathrm{mC}$. It has been subsequently shown that TET enzymes mediate the oxidation of $5 \mathrm{mC}$ to $5 \mathrm{hmC}$ (as well as 5 -formylcytosine $(5 \mathrm{fC})$ and 5-carboxylcytosine $(5 \mathrm{caC})$ ) in vivo and that TET proteins are expressed and differentially localized during preimplantation development (Gu et al. 2011, He et al. 2011, lqbal et al. 2011, Wossidlo et al. 2011). Specifically, TET3 primarily localizes to the paternal pronucleus (Fig. 1) and is thought to be responsible for the observed rapid demethylation. Importantly, Gu et al. (2011) showed that the loss of $5 \mathrm{mC}$ corresponds with a concomitant gain in $5 \mathrm{hmC}$. In both pronuclei, $5 \mathrm{mC}$ is present until $\mathrm{PN} 3$, and by late PN3, there is a detectable decrease in $5 \mathrm{mC}$ and an increase in 5hmC (Fig. 1; Gu et al. 2011, lqbal et al. 2011, Wossidlo et al. 2011). It was also shown that Tet proteins convert $5 \mathrm{mC}$ to $5 \mathrm{fC}$ and $5 \mathrm{caC}$ as well, suggesting that Tet-mediated oxidation results in three oxidative forms for cytosine in vivo (Inoue 2011), ultimately resulting in replacement of the oxidized base with unmethylated cytosine by base excision repair or replication-dependent diffusion. Additionally, oxidation of $5 \mathrm{mC}$ has been shown in other mammalian zygotes, indicating a conserved mechanism of demethylation (Wossidlo et al. 2011).

Surprisingly, deletion of Tet 3 activity results in retention of $5 \mathrm{mC}$ in the paternal pronucleus and inappropriate gene activation at many loci, but only mild global phenotype (reduced viability (Gu et al. 2011)). Tet3 mediated 


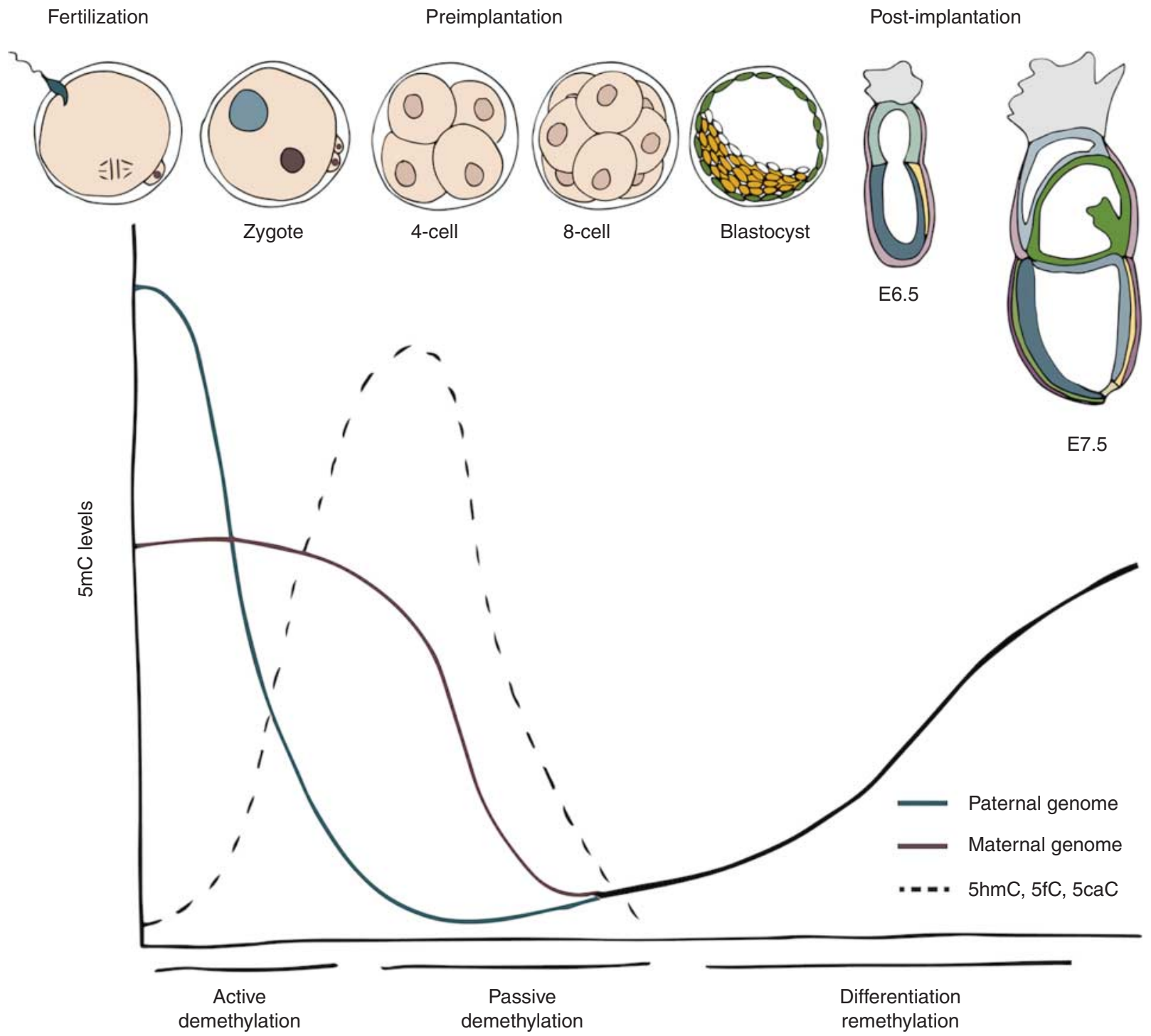

Figure 2 DNA methylation dynamics from fertilization through gastrulation. The three main phases of methylation change are illustrated. During zygotic stages, the paternal genome undergoes active demethylation (blue line). This active demethylation is evident by sharply increased levels of oxidative products $(5 \mathrm{mC}$ to $5 \mathrm{hmC}, 5 \mathrm{fC}$ and $5 \mathrm{caC}$ ) in the paternal pronucleus. Passive replication-dependent demethylation (predominantly in the maternal pronucleus) occurs though exclusion of DNMTs from the nucleus during early preimplantation (red line). Lowest levels of methylation are reached between the morula to blastocyst stage, when methylation levels begin to rise. During blastocyst formation and gastrulation, the genome becomes re-methylated to levels consistent with somatic cells (black line).

hydrolysis of $5 \mathrm{mC}$ also occurs during reprogramming after SCNT cloning - Tet 3 localizes to the pseudo-pronucleus in recombined zygotes. In SCNT embryos made with Tet3null host oocytes, there is no $5 \mathrm{hmC}$ present in the pseudopronucleus, further indicating the role of Tet 3 in active demethylation (Wossidlo et al. 2011, Gu et al. 2011).

These recent studies offered the prevailing idea that demethylation during preimplantation development occurred via i) active DNA demethylation of the paternal pronuclei mediated by Tet3 and thymine DNA glycosylase (TDG)-mediated base excision repair (reviewed in Kohli \& Zhang (2013)) and ii) passive, replicationdependent dilution loss of methylation of the maternal genome due to lack of Dnmt1 in the nucleus (Howell et al. 2001).

However, recent work is shifting the hypotheses about the mechanisms responsible in vivo. Using whole genome approaches to assess cytosine methylation patterns, it has been shown that Tet3-mediated demethylation is only partially responsible for paternal demethylation and that active demethylation also occurs in the maternal PN (Guo et al. 2014a, Shen et al. 2014). Furthermore, although Tet3-mediated oxidation is required for active demethylation, TDG-mediated base excision repair is not (Guo et al. 2014a). Additionally, it appears that there is conflicting evidence regarding the 
role that replication-dependent demethylation plays in removing methylation from the paternal genome. By blocking replication of the paternal pronucleus, Shen et al. (2014) showed diminished demethylation in the paternal pronucleus even though Tet3 activity is present, indicating that replication is also involved in the demethylation of the paternal PN. Adding additional ambiguity is the fact that that Tet3-mediated demethylation is largely dispensable for successful development (Peat et al. 2014, Shen et al. 2014, Inoue et al. 2015).

Taken together the mechanisms that reprogram sperm and oocyte specific DNA methylation are not mutually exclusive as once predicted, and these recent stories indicate that there are likely unknown mechanisms also contributing to DNA methylation dynamics during preimplantation. With these advances, there are three main modes of DNA demethylation: i) active Tet3-mediated oxidation (predominantly in the paternal pronucleus); ii) replication-dependent dilution of Tet3-oxidative products, which plays a major role in demethylation of the paternal pronucleus and iii) replication-dependent (Tet3-independent) dilution of $5 \mathrm{mC}$ (predominantly in the maternal pronucleus). As our technical abilities evolve, it will be interesting to determine the interplay of these mechanisms within the same cells in vivo, define the specific loci at which each occurs and identify whether there are differing roles influencing cell fate decisions.

If Tet 3 is present in the oocyte but only acts primarily on the paternal genome, there must be a protective mechanism to prevent conversion of maternal $5 \mathrm{mC}$. One candidate for this maternal genome protection is PGC7/Stella, a DNA-binding protein expressed during germ cell specification and in gonads and oocytes (Saitou et al. 2002, Sato et al. 2002). PGC7 null embryos fail to complete preimplantation and there is a loss of $5 \mathrm{mC}$ in both pronuclei, indicating a protective role in the maternal pronucleus. Additionally, PGC7/Stella is targeted to differentially methylated regions (DMRs) of imprinted genes in the early embryo (Nakamura et al. 2007), supporting a functional role in blocking Tet3-mediated demethylation.

PGC7/Stella is able to protect the maternal pronucleus by binding to $\mathrm{H} 3 \mathrm{~K} 9 \mathrm{me} 2$, which is a distinguishing feature of the maternal pronucleus. Loss of $\mathrm{H} 3 \mathrm{~K} 9 \mathrm{me} 2$ by ectopic Jndm2a, a H3K9 methylation/dimethylation-specific demethylase, leads to loss of $5 \mathrm{mC}$ in both the maternal and parental pronuclei. PGC7/Stella also binds to H3K9me2 regions of the paternal pronucleus, including DMRs, which are not subject to protamine replacement. Tet3 is inhibited by PGC7/Stella, thus offering protection from active demethylation (Nakamura et al. 2012).

\section{Imprinted loci are protected from demethylation}

While most of the genome undergoes global DNA demethylation, imprinted loci are protected and retain parent of origin DMRs (Branco 2008, Cirio 2008, Hirasawa 2008). It is clear that Dnmt1 is required for the maintenance of these imprinted sites (Bourc'his et al. 2001), even though it is largely excluded from the nucleus (Hirasawa 2008). Stella is also known to protect these loci, including some imprinted sites of the paternal genome. Additionally, Zfp57, a KRAB zinc finger protein, and Trim28 have also been shown to be required for integrity of ICRs in the early embryo. Trim 28 interacts with Zfp57 to target it to specific imprinted sites, resulting in recruitment of repressive complexes including NuRD, SETDB1 and DMNTs (lyengar et al. 2011, Quenneville et al. 2011, Zuo et al. 2012). While loss of maternal Zfp57 can be rescued by paternal expression, loss of maternal Trim28 is lethal ( $\mathrm{Li}$ et al. 2008, Messerschmidt et al. 2012), due in part to the variation in loss of imprinted expression (Messerschmidt et al. 2012).

\section{Early DNA demethylation dynamics in other mammalian species}

Preimplantation DNA demethylation dynamics are largely the same in mouse and human embryos. However, this is not the case in all mammals, indicating distinct epigenetic reprogramming in different species. During the PN stages and in the first cell divisions, human, mouse and rat zygotes lose the majority of their paternal 5mC (Dean et al. 2001, Zaitseva et al. 2007). In contrast, both bovine and goat embryos retain an intermediate level of $5 \mathrm{mC}$ in the paternal pronuclei (Park et al. 2010, Wossidlo et al. 2010). Strikingly, sheep, pig and rabbit embryos retain $5 \mathrm{mC}$ during the $\mathrm{PN}$ stages and throughout preimplantation development (Beaujean et al. 2004, Jeong et al. 2007, Reis e Silva et al. 2012). In sheep, levels of $5 \mathrm{mC}$ drop during the 2-cell stage, but then increase at the 16-cell stage, and the ICM maintains levels of DNA methylation but the TE levels decrease dramatically (Young \& Beaujean 2004).

These comparative studies illustrate the differences in timing and degree of $5 \mathrm{mC}$ loss during preimplantation among different mammalian species. These differences may be due in part to variation in zygotic genome activation, but they may also hint at differences in methylation reprogramming requirements needed to reach a totipotent state. These data also support the idea that active, Tet3-mediated demethylation in mice is not required for normal preimplantation development (Peat et al. 2014, Shen et al. 2014).

\section{Next-generation sequencing to assess global DNA methylation dynamics during preimplantation development}

Next-generation sequencing, including reduced representation bisulfite sequencing (RRBS) and wholegenome bisulfite sequencing (WGBS) now allow 
assessment of global DNA methylation reprogramming with high resolution even from limited numbers of cells. Confirming earlier work, methylation across the genome is observed at relatively low levels in oocytes and early preimplantation stages, while sperm and postimplantation embryos have methylation similar to that of somatic cells (Smith et al. 2012, Guo et al. 2014a,b, Peat et al. 2014). These newer technologies have allowed for refined assessment of methylation changes across the genome during precise developmental stages, examination of specific classes of DNA sequence elements and comparison of mouse and human preimplantation embryos.

\section{DNA methylation dynamics in human preimplantation embryos}

Two groups recently examined genome-wide DNA methylation changes in human oocyte, sperm, zygote, pre- and post-implantation stages, using RRBS and WGBS (Smith et al. 2012, Guo et al. 2014a). Similar to mouse, both groups found that human sperm is highly methylated (although less than mouse sperm) and human oocytes have intermediate levels of methylation. The postfertilization demethylation kinetics are also similar in the human zygote (Smith et al. 2012). Guo et al. (2014a) note that the greatest loss of DNA methylation occurred between the 1- to 2-cell stage in human embryos, rather than during PN stages (as is the case in the mouse). This could indicate that differences in the rate of active demethylation also correlates with the timing of zygotic genome activation, which occurs later in humans (Beaujean et al. 2004). Because bisulfite sequencing used in these studies did not distinguish between $5 \mathrm{mC}$ and the oxidative products of Tet-mediated demethylation, the distinct timing in mouse and human embryos may reflect a difference in the oxidation rates of $5 \mathrm{mC}$ or Tet activity between species. Paternal genome demethylation in humans is similar to observations in mouse zygotes, in that the majority of methylation is rapidly lost and only low levels of methylation remain during preimplantation. Levels of methylation in the maternal pronucleus are similar to mice, but the genomic regions that are demethylated are divergent. Additionally, unlike in mice, the majority of sperm and oocyte-specific DMRs regain their full methylation following implantation (Smith et al. 2012, Guo et al. 2014a).

Comparison of genome-wide methylation with singlecell RNA sequencing data (Yan et al. 2013) confirmed the previously observed negative correlation between promoter methylation and gene expression and highlighted that this inverse relationship strengthens after the MZT in human embryos (Smith et al. 2012, Guo et al. $2014 b$ ). Genes that had increased promoter methylation after the blastocyst stage showed a predicted decrease in expression in post-implantation-stage embryos (Guo et al. 2014b). Also as expected, changes in DNA methylation during preimplantation influence the repression of transposable elements. SINE/variable number of tandem repeat/Alu elements (SVAs) expression increases after the 2-cell stage, when rapid demethylation occurs. This expression is maintained until the morula stage, when expression decreases, presumably as the genome is re-methylated - a trend which continues postimplantation (Smith et al. 2012, Guo et al. 2014b).

While many repeat elements undergo loss of DNA methylation and increased expression, the evolutionary age of the transposable element appears to influence the retention of methylation during preimplantation development. Evolutionarily younger elements, which are still capable of transposition are relatively resistant to demethylation while their evolutionarily older counterparts that have lost the ability to jump are readily demethylated along with coding genes. This might hint at the evolutionary origins of methylation/demethylation dynamics in mammalian preimplantation development (Wang et al. 2014).

\section{Histone modifications during preimplantation}

In addition to DNA methylation changes, chromatin organization and histone modifications play a critical role in establishing a totipotent embryo, as well as directing the first lineage decisions. Chromatin is a highly organized and dynamic nuclear structure containing DNA, histones and many other proteins. Nucleosomes, the basic building block of chromatin are comprised of two each of histone $\mathrm{H} 2 \mathrm{~A}, \mathrm{H} 2 \mathrm{~B}, \mathrm{H} 3$ and $\mathrm{H} 4$. It is well established that the $\mathrm{N}$-terminal tails of these core histones are subject to post-translational modifications (PTMs), which play a fundamental role in influencing gene expression patterns among disparate cell types (Fischle et al. 2003). Histone PTMs include acetylation, methylation, phosphorylation, ubiquitination and others, which occur at specific amino acid residues catalyzed by specific enzymes (Strahl \& Allis 2000, Tan et al. 2011). Additional complexity arises in that methylation at lysines or arginines may exist in distinct forms: mono-, di-, or trimethyl for lysines and mono- or dimethyl on arginine residues (Kouzarides 2007). A general theme has emerged in which PTMs are catalyzed by opposite functional pairs of enzymes.

Many studies have revealed functional themes where histone PTMs correlate with gene expression patterns. For example, lysine acetylation is commonly considered to be an active mark that correlates with chromatin accessibility and active transcription, whereas histone lysine methylation can be either active or repressive depending on the particular lysine residue that is modified (Tsukada et al. 2006, Bernstein et al. 2007). Recent large-scale efforts supported by the Roadmap Epigenomics Project are defining 'chromatin states' in many diverse tissues - that is, combinations of histone modifications, DNA methylation and transcription factor binding that correlate with 
functional property of a particular locus (http://www. roadmapepigenomics.org/publications/).

\section{Histone modification during preimplantation embryo development}

Studies of early embryonic development have shown that shortly after fertilization, many histone modifications are observed asymmetrically in the parental haploid genomes prior to $\mathrm{PN}$ fusion (summarized in Fig. 3). For example, in mice, H3K27ac, H4K5ac and $\mathrm{H} 4 \mathrm{~K} 16 \mathrm{ac}$ are only detectable in the paternal PN of early zygotes (Adenot et al. 1997, Stein et al. 1997, Hayashi-Takanaka et al. 2011). Conversely, all forms of H3K4 methylation (me1, me2 and me3) are observed in maternal PN (Lepikhov \& Walter 2004, Santenard et al. 2010), and H3K9me2 and me 3 are also significantly higher in the maternal PN (Lepikhov \& Walter 2004, Wongtawan et al. 2011, Beaujean 2014). H3K27me1 is present in both PNs, but H3K27me2 and -me3 occur extensively in the maternal PN (Erhardt et al. 2003, Santos et al. 2005, Santenard et al. 2010). Additionally, H3K9me3S1OP, H3K36me3 and H4K2Ome3 are also found exclusively in the maternal $\mathrm{PN}$ at early postfertilization stages (Boskovic et al. 2012, Ribeiro-Mason et al. 2012, Beaujean 2014). Although the functional significance of these asymmetric PTMs remains largely unknown, it highlights the distinct reprogramming that is required for the paternal and maternal $\mathrm{PN}$ for proper embryonic genome activation and embryo development (Ribeiro-Mason et al. 2012, Beaujean 2014).

Histone PTMs also play key roles in remodeling of chromatin configuration and DNA methylation. In mice, the increase of $\mathrm{H} 3 \mathrm{~K} 79$ me by forced expression of DOT1L causes premature chromocenter formation and developmental arrest of 2-cell embryos (Ooga et al. 2013). Additionally, deletion of the methyltransferase Setdb1 in mouse embryonic stem cells leads to the reduction of H3K9me3 and an overall decrease of DNA methylation levels at specific loci (Leung et al. 2014). In porcine embryos, disturbed H3K4me3-H3K27me3 balance after knockdown of demethylase $\mathrm{Kdm} 5 \mathrm{~b}$ can cause increased expressions of Tet family members (Huang et al. 2015), which are found to be crucial for the interactions between histone modification and DNA methylation in mouse embryonic stem cells (Sui et al. 2012).

Functional studies of the roles of specific modifications are just beginning, using genetic strategies to add or remove specific enzymatic activities to embryos. For example in mice, hyperacetylation of histone $\mathrm{H} 4$ mediated by knockdown of HDAC1 causes developmental delay (Ma \& Schultz 2008). Knockdown of either Ing2 (H3K4me3 methyltransferase activity) or RNF20 (histone $\mathrm{H} 2 \mathrm{~B}$ monoubiquitination) results in arrest at the morula stage (Ooga et al. 2015, Zhou et al. 2015). Depletion of H4K20me1 by knockout of the PR-Set7 gene induces early embryonic lethality prior to the 8-cell stage (Oda et al. 2009), and our lab has shown critical roles of H3K36me3 during preimplantation development by knockdown of CTR9/PAF1 (Zhang et al. 2013a). Other recent examples include studies in mice showing that maternal-specific $\mathrm{H} 3 \mathrm{~K} 9 \mathrm{me} 3$ is enriched at the Xist promoter region and prevents maternal Xist activation (Fukuda et al. 2014); increased H3K4me2 results in abnormal expression of elF-4C/Oct4 and arrest at the 2-cell stage (Shao et al. 2008); and that PRC1 binding to H3K27me3 plays an indispensable role in embryonic genome activation and developmental progression (Posfai et al. 2012). Although precise in the removal of specific gene function, these studies highlight the difficulty in assigning specific function to a particular modification or enzymatic activity since the phenotype is often developmental failure and misregulation of many genes. It is only very recently that next-generation technologies allow for very low input such that
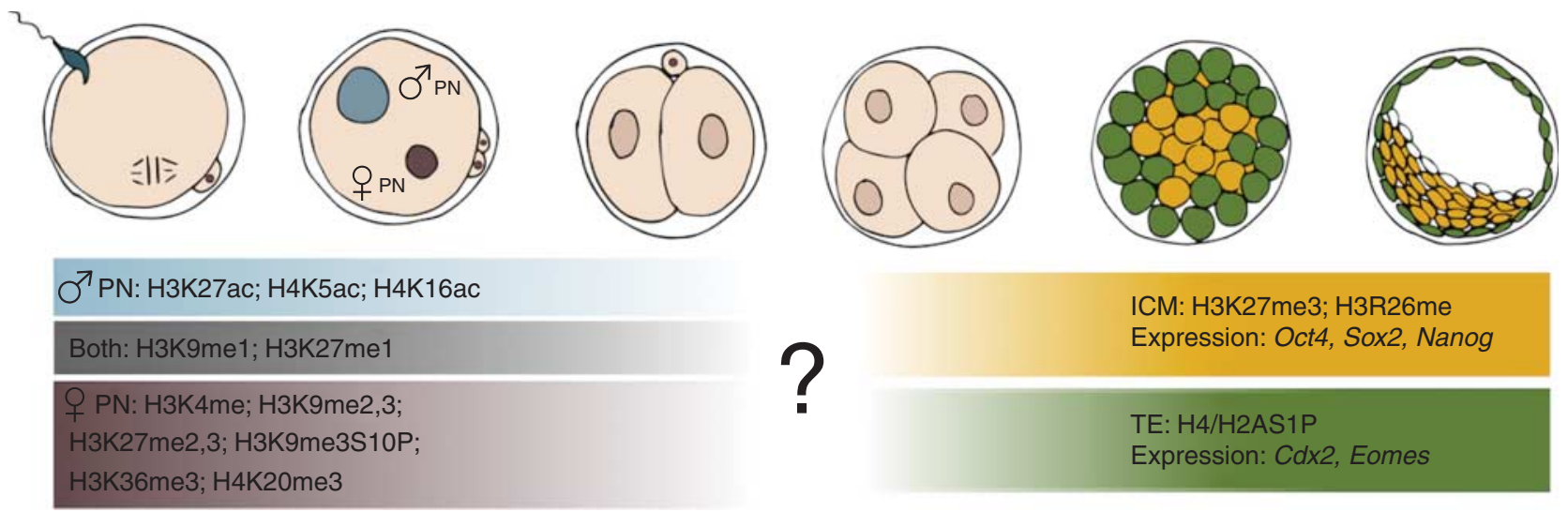

ICM: H3K27me3; H3R26me

Expression: Oct4, Sox2, Nanog

TE: H4/H2AS1P

Expression: $\mathrm{Cd} 2 \mathrm{2}$, Eomes

Figure 3 Differential histone modification during preimplantation development. After fertilization, the parental pronuclei are differentially enriched with many distinct histone modifications (left side: list of PTMs). Little data is available regarding the timing and mechanisms resulting after pronuclear fusion that result in largely homogenous PTMs during cleavage stages (indicated by the question mark). By the time ICM and TE begin to differentiate, these cell lineages have acquired distinct epigenetic signatures and gene expression patterns (right side). 
investigators can determine which loci across the genome are altered in these knockout/knockdown embryos (Brind'Amour et al. 2015).

Relevant to artificial reproductive technologies, histone modifications are sensitive to manipulations during preimplantation, potentially altering epigenomic patterns (Feil \& Fraga 2012, Dupont et al. 2012). For example, in the mouse, H3K4me3 is significantly lower in the in vitro fertilized embryos compared with in vivo fertilized embryos (Wu et al. 2012). Similarly lower levels of H3K27me3 are found in the ICM of heatedsperm-derived blastocysts when compared to untreatedsperm-derived blastocysts (Chao et al. 2012), and cryopreservation can alter H4K12ac patterns in both oocytes and zygotes (Suo et al. 2010). Despite these observations, it remains unclear if altered PTM levels persist in offspring or if surviving individuals contain appropriate epigenomic information - possibly correcting the epigenome during cell lineage differentiation at post-implantation stages.

\section{Histone modifications in ICM and TE lineage specification}

In mouse embryos, transcription factors such as Oct4, Sox 2 and Nanog are enriched in cells of the ICM and function to both promote pluripotency and resist differentiation. Conversely, in TE, transcription factors such as $\mathrm{Cd} \times 2$ and Eomes become upregulated, promoting differentiation. In contrast to the mouse, Oct 4 and $\mathrm{Cdx} 2$ are co-expressed in the ICM and TE of bovine and porcine embryos, and the mechanisms of molecular differentiation remain largely unknown (Kirchhof et al. 2000).

This first lineage specification is critical for implantation and successful development. DNA methylation has been shown to be dispensable for growth and differentiation of the extraembryonic lineages (Sakaue et al. 2010), suggesting that appropriate histone modifications may provide key epigenetic information directing gene expression and lineage specification. Once the TE and ICM become distinct, they exhibit asymmetries in specific histone PTMs. For example, in the mouse, $\mathrm{H} 4$ - and H2AS1P are increased in the TE cells (Sarmento et al. 2004), while H3K27me3 is enriched in the ICM (Erhardt et al. 2003). At the 4-cell stage, blastomeres have different levels of methylated H3R26me and those cells with higher H3R26me are more likely to result in ICM cell fate. Overexpression of the H3R26 methyltransferase CARM1 results in increased expression Nanog and Sox2, suggesting that pluripotency factor expression is influenced by locus-specific H3R26me (Torres-Padilla et al. 2007). Other examples include studies showing that repressive $\mathrm{H} 3 \mathrm{~K} 9 \mathrm{me} 3$ at the $\mathrm{Cd} 22$ promoter is important for maintaining pluripotency and loss of associated methyltransferase ESET in early embryos results in ICM failure (Yeap et al. 2009). However, in TE lineage, Suv39h methyltransferase mediates repressive $\mathrm{H} 3 \mathrm{~K} 9 \mathrm{me} 3$ at ICMspecific gene promoters in the TE lineage (Alder et al. 2010, Rugg-Gunn et al. 2010). These studies highlight that even the same histone modification can be finely tuned by distinct enzymes to influence lineage specification in different cell populations.

There are ever growing observations of locus specific enrichment of histone modifications correlating with lineage decisions during preimplantation development. For example, $\mathrm{H} 3 \mathrm{~K} 4 \mathrm{me} 3$ and $\mathrm{H} 3 \mathrm{~K} 27 \mathrm{me} 3$ are enriched at promoters of genes exclusively expressed in ICM or TE in both murine and bovine embryos (Dahl et al. 2010, Herrmann et al. 2013). It was also recently shown that loss of repressive $\mathrm{H} 3 \mathrm{~K} 27 \mathrm{me} 3$ participation at TE-specific genes is essential for TE lineage development and embryo implantation (Saha et al. 2013, Paul \& Knott 2014). In addition to methylation of histone $\mathrm{H} 3$ residues, acetylation of histone $\mathrm{H} 4$ (H4K8ac and H4K12ac) has also been implicated in early lineage specification (VerMilyea et al. 2009, Zhang et al. 2013b).

A handful of histone-modifying proteins thought to be central to epigenetic programing during development have knock-out phenotypes only apparent after preimplantation. These include members of Polycomb Repressive Complex 2 (Eed, Ezh2 and Suz12) as well as the H3K9 methyltransferases G9a and Eset. It remains unclear if the timing of null phenotypes is due to functional redundancy with other genes or maternal loading of RNA/protein, or if the modifications they perform are in fact not required until gastrulation (or later). There are a few histonemodifying enzyme knock-out phenotypes in mice that do result in lethality during preimplantation, some of which show lineage-specific defects. Loss of the histone H3K9 demethylase Jmjd2C results in morula arrest and null embryos show reduced levels of ICM-specific gene transcription, suggesting a failure to maintain pluripotency (Wang et al. 2010). Similarly, null embryos of several members of the NuRD complex (Sin3A, Suds3, Arid4b (McDonel et al. 2009)) and PAF1 complex (Ctr9 and Rtf1 (Ding et al. 2009, Zhang et al. 2013a)) do form blastocysts but show defects in ICM proliferation as a major cause of developmental lethality and failure. It is perhaps not so surprising that knockout of genes with distinct functions (such as Sin 3A and Ctr9) result in similar defects in maintenance of ICM potency, which is of the utmost importance for continued development and requires myriad proteins to accomplish.

\section{Moving forward}

As described above, a wide array of covalent histone modifications are now recognized to occur in vivo and correlate with distinct transcriptional states and/or chromatin conformation. However, knowledge about the role of histone modifications during development is mostly limited to reports of changes in global patterns apparent by immunofluorescence with antibodies 
directed against specific modifications (reviewed in Beaujean (2014)). While these descriptive studies are an essential beginning, little is known about the functional importance of these modifications. In vivo analysis of the role of histone modifications at specific loci during early development is only just beginning, and the relative lack of functional data is due to several factors including: i) limitations in our ability to efficiently generate maternal and zygote null embryos at the same time, ii) limitations in our ability to assess histone modifications at specific loci from very small numbers of cells and iii) an inability to alter specific modifications at specific loci. Due to the combinatorial nature of the histone code and the difficulty in functionally preventing one particular modification at one locus in vivo, it is currently not feasible to simply ask, 'What is the role of a specific histone modification at a specific genomic locus during development'. Fortunately, this type of epigenetic engineering has come to the fore and many groups are currently working to develop in vivo epigenetic targeting tools.

With greatly enhanced access to next-generation sequencing technologies, there is ever-growing opportunity to probe genome-wide methylation patterns at single-base/nucleosome resolution in diverse cell populations, and improved techniques are pushing WGBS towards single-cell sequencing. Additionally, multiple methods are now readily available for the discrimination of $5 \mathrm{mC}$ and $5 \mathrm{hmC}$ at a single base resolution. Combining DNA methylation analysis with ChIP-seq and RNA-seq during preimplantation development will allow for a comprehensive cataloguing of early epigenetic reprogramming dynamics. Cross-species comparison of these dynamics at specific loci and the capability to functionally test the importance of specific modifications will allow for deeper understanding of how epigenetic dynamics influence preimplantation development, the transition from gametes to totipotency and the requirements of lineage differentiation.

\section{Declaration of interest}

The authors declare that there is no conflict of interest that could be perceived as prejudicing the impartiality of the review.

\section{Funding}

This was supported in part by March of Dime Research Grant \#6-FY11-367 and NIH 1R21HD078942-01 to J Mager.

\section{References}

Adenot PG, Mercier Y, Renard JP \& Thompson EM 1997 Differential H4 acetylation of paternal and maternal chromatin precedes DNA replication and differential transcriptional activity in pronuclei of 1-cell mouse embryos. Development 124 4615-4625.
Alder O, Lavial F, Helness A, Brookes E, Pinho S, Chandrashekran A, Arnaud P, Pombo A, O'Neill L \& Azuara V 2010 Ring1B and Suv39h1 delineate distinct chromatin states at bivalent genes during early mouse lineage commitment. Development 137 2483-2492. (doi:10.1242/dev.048363)

Arand J, Spieler D, Karius T, Branco MR, Meilinger D, Meissner A, Jenuwein T, Xu G, Leonhardt H, Wolf V et al. 2012 In vivo control of $\mathrm{CpG}$ and non-CpG DNA methylation by DNA methyltransferases. PLoS Genetics 8 e1002750. (doi:10.1371/journal.pgen.1002750)

Balhorn R 2007 The protamine family of sperm nuclear proteins. Genome Biology 8 227. (doi:10.1186/gb-2007-8-9-227)

Bartolomei MS, Webber AL, Brunkow ME \& Tilghman SM 1993 Epigenetic mechanisms underlying the imprinting of the mouse $\mathrm{H} 19$ gene. Genes and Development 7 1663-1673. (doi:10.1101/gad.7.9.1663)

Beaujean N 2014 Histone post-translational modifications in preimplantation mouse embryos and their role in nuclear architecture. Molecular Reproduction and Development 81 100-112. (doi:10.1002/mrd.22268)

Beaujean N, Hartshorne G, Cavilla J, Taylor J, Gardner J, Wilmut I, Meehan R \& Young L 2004 Non-conservation of mammalian preimplantation methylation dynamics. Current Biology 14 R266-R267. (doi:10.1016/j.cub.2004.03.019)

Bernstein BE, Meissner A \& Lander ES 2007 The mammalian epigenome. Cell 128 669-681. (doi:10.1016/j.cell.2007.01.033)

Biggers JD, Bell JE \& Benos DJ 1988 Mammalian blastocyst: transport functions in a developing epithelium. American Journal of Physiology 255 C419-C432.

Borgel J, Guibert S, Li Y, Chiba H, Schubeler D, Sasaki H, Forne T \& Weber M 2010 Targets and dynamics of promoter DNA methylation during early mouse development. Nature Genetics 42 1093-1100. (doi:10.1038/ng.708)

Boskovic A, Bender A, Gall L, Ziegler-Birling C, Beaujean N \& TorresPadilla ME 2012 Analysis of active chromatin modifications in early mammalian embryos reveals uncoupling of H2A.Z acetylation and $\mathrm{H} 3 \mathrm{~K} 36$ trimethylation from embryonic genome activation. Epigenetics 7 747-757. (doi:10.4161/epi.20584)

Bostick M, Kim JK, Esteve PO, Clark A, Pradhan S \& Jacobsen SE 2007 UHRF1 plays a role in maintaining DNA methylation in mammalian cells. Science 317 1760-1764. (doi:10.1126/science.1147939)

Bourc'his D, Xu GL, Lin CS, Bollman B \& Bestor TH 2001 Dnmt3L and the establishment of maternal genomic imprints. Science 294 2536-2539. (doi:10.1126/science.1065848)

Branco MR, Oda M \& Reik W 2008 Safeguarding parental identity: Dnmt1 maintains imprints during epigenetic reprogramming in early embryogenesis. Genes and Development 22 1567-1571. (doi:10.1101/gad. 1690508)

Braun RE 2001 Packaging paternal chromosomes with protamine. Nature Genetics 28 10-12.

Brind'Amour J, Liu S, Hudson M, Chen C, Karimi MM \& Lorincz MC 2015 An ultra-low-input native ChIP-seq protocol for genome-wide profiling of rare cell populations. Nature Communications 6 6033. (doi:10.1038/ ncomms7033)

Chao SB, Chen L, Li JC, Ou XH, Huang XJ, Wen S, Sun QY \& Gao GL 2012 Defective histone $\mathrm{H} 3 \mathrm{~K} 27$ trimethylation modification in embryos derived from heated mouse sperm. Microscopy and Microanalysis 18 476-482. (doi:10.1017/S1431927612000396)

Cirio MC, Ratnam S, Ding F, Reinhart B, Navara C \& Chaillet JR 2008 Preimplantation expression of the somatic form of Dnmt1 suggests a role in the inheritance of genomic imprints. BMC Developmental Biology 89. (doi:10.1186/1471-213X-8-9)

Dahl JA, Reiner AH, Klungland A, Wakayama T \& Collas P 2010 Histone H3 lysine 27 methylation asymmetry on developmentally-regulated promoters distinguish the first two lineages in mouse preimplantation embryos. PLoS ONE 5 e9150. (doi:10.1371/journal.pone.0009150)

Dean W, Santos F, Stojkovic M, Zakhartchenko V, Walter J, Wolf E \& Reik W 2001 Conservation of methylation reprogramming in mammalian development: aberrant reprogramming in cloned embryos. PNAS 98 13734-13738. (doi:10.1073/pnas.241522698)

Ding L, Paszkowski-Rogacz M, Nitzsche A, Slabicki MM, Heninger AK, de Vries I, Kittler R, Junqueira M, Shevchenko A, Schulz H et al. 2009 A genome-scale RNAi screen for Oct4 modulators defines a role of the Paf1 complex for embryonic stem cell identity. Cell Stem Cell 4 403-415. (doi:10.1016/j.stem.2009.03.009) 
Dupont C, Cordier AG, Junien C, Mandon-Pepin B, Levy R \& ChavattePalmer P 2012 Maternal environment and the reproductive function of the offspring. Theriogenology 78 1405-1414. (doi:10.1016/j.theriogenology.2012.06.016)

Erhardt S, Su IH, Schneider R, Barton S, Bannister AJ, Perez-Burgos L, Jenuwein T, Kouzarides T, Tarakhovsky A \& Surani MA 2003 Consequences of the depletion of zygotic and embryonic enhancer of zeste 2 during preimplantation mouse development. Development 130 4235-4248. (doi:10.1242/dev.00625)

Feil R \& Fraga MF 2012 Epigenetics and the environment: emerging patterns and implications. Nature Reviews. Genetics 13 97-109. (doi:10.1038/ nrg3142)

Fischle W, Wang Y \& Allis CD 2003 Binary switches and modification cassettes in histone biology and beyond. Nature 425 475-479. (doi:10. 1038/nature02017)

Fleming TP, Sheth B \& Fesenko I 2001 Cell adhesion in the preimplantation mammalian embryo and its role in trophectoderm differentiation and blastocyst morphogenesis. Frontiers in Bioscience 6 D1000-D1007. (doi:10.2741/Fleming)

Fouse SD, Shen Y, Pellegrini M, Cole S, Meissner A, Van Neste L, Jaenisch R \& Fan G 2008 Promoter CpG methylation contributes to ES cell gene regulation in parallel with Oct4/Nanog. PcG complex, and histone H3 K4/K27 trimethylation. Cell Stem Cell 2 160-169. (doi:10.1016/j.stem. 2007.12.011)

Fukuda A, Tomikawa J, Miura T, Hata K, Nakabayashi K, Eggan K, Akutsu H \& Umezawa A 2014 The role of maternal-specific H3K9me3 modification in establishing imprinted X-chromosome inactivation and embryogenesis in mice. Nature Communications 5 5464. (doi:10. 1038/ncomms6464)

Gaudet F, Talbot D, Leonhardt H \& Jaenisch R 1998 A short DNA methyltransferase isoform restores methylation in vivo. Journal of Biological Chemistry 273 32725-32729. (doi:10.1074/jbc.273.49. 32725)

Gu TP, Guo F, Yang H, Wu HP, Xu GF, Liu W, Xie ZG, Shi L, He X, Jin SG et al. 2011 The role of Tet3 DNA dioxygenase in epigenetic reprogramming by oocytes. Nature 477 606-610. (doi:10.1038/ nature10443)

Guo F, Li X, Liang D, Li T, Zhu P, Guo H, Wu X, Wen L, Gu TP, Hu B et al. 2014a Active and passive demethylation of male and female pronuclear DNA in the Mammalian zygote. Cell Stem Cell 15 447-458. (doi:10. 1016/j.stem.2014.08.003)

Guo H, Zhu P, Yan L, Li R, Hu B, Lian Y, Yan J, Ren X, Lin S, Li J et al. $2014 b$ The DNA methylation landscape of human early embryos. Nature $\mathbf{5 1 1}$ 606-610. (doi:10.1038/nature13544)

Hayashi-Takanaka Y, Yamagata K, Wakayama T, Stasevich TJ, Kainuma T, Tsurimoto T, Tachibana M, Shinkai Y, Kurumizaka H, Nozaki N et al. 2011 Tracking epigenetic histone modifications in single cells using Fabbased live endogenous modification labeling. Nucleic Acids Research 39 6475-6488. (doi:10.1093/nar/gkr343)

He YF, Li BZ, Li Z, Liu P, Wang Y, Tang Q, Ding J, Jia Y, Chen Z, Li L et al. 2011 Tet-mediated formation of 5-carboxylcytosine and its excision by TDG in mammalian DNA. Science 333 1303-1307. (doi:10.1126/ science.1210944)

Herrmann D, Dahl JA, Lucas-Hahn A, Collas P \& Niemann H 2013 Histone modifications and mRNA expression in the inner cell mass and trophectoderm of bovine blastocysts. Epigenetics 8 281-289. (doi:10.4161/epi.23899)

Hirasawa R, Chiba H, Kaneda M, Tajima S, Li E, Jaenisch R \& Sasaki H 2008 Maternal and zygotic Dnmt1 are necessary and sufficient for the maintenance of DNA methylation imprints during preimplantation development. Genes and Development 22 1607-1616. (doi:10.1101/ gad.1667008)

Howell CY, Bestor TH, Ding F, Latham KE, Mertineit C, Trasler JM \& Chaillet JR 2001 Genomic imprinting disrupted by a maternal effect mutation in the Dnmt1 gene. Cell 104 829-838. (doi:10.1016/S00928674(01)00280-X)

Howlett SK \& Reik W 1991 Methylation levels of maternal and paternal genomes during preimplantation development. Development 113 119-127.

Huang Y, Pastor WA, Shen Y, Tahiliani M, Liu DR \& Rao A 2010 The behaviour of 5-hydroxymethylcytosine in bisulfite sequencing. PLoS ONE 5 e8888. (doi:10.1371/journal.pone.0008888)
Huang J, Zhang H, Wang X, Dobbs KB, Yao J, Qin G, Whitworth K, Walters EM, Prather RS \& Zhao J 2015 Impairment of preimplantation porcine embryo development by histone demethylase KDM5B knockdown through disturbance of bivalent $\mathrm{H} 3 \mathrm{~K} 4 \mathrm{me} 3-\mathrm{H} 3 \mathrm{~K} 27 \mathrm{me} 3$ modifications. Biology of Reproduction 92 72. (doi:10.1095/biolreprod.114.122762)

Illingworth RS, Gruenewald-Schneider U, Webb S, Kerr AR, James KD, Turner DJ, Smith C, Harrison DJ, Andrews R \& Bird AP 2010 Orphan CpG islands identify numerous conserved promoters in the mammalian genome. PLoS Genetics 6 e1001134. (doi:10.1371/journal.pgen. 1001134)

Inoue A \& Zhang Y 2011 Replication-dependent loss of 5-hydroxymethylcytosine in mouse preimplantation embryos. Science 334 194. (doi:10. 1126/science.1212483)

Inoue A, Shen L, Matoba S \& Zhang Y 2015 Haploinsufficiency, but not defective paternal $5 \mathrm{mC}$ oxidation, accounts for the developmental defects of maternal Tet3 knockouts. Cell Reports 10 463-470. (doi:10. 1016/j.celrep.2014.12.049)

Iqbal K, Jin SG, Pfeifer GP \& Szabo PE 2011 Reprogramming of the paternal genome upon fertilization involves genome-wide oxidation of 5-methylcytosine. PNAS $\mathbf{1 0 8}$ 3642-3647. (doi:10.1073/pnas. 1014033108)

Iyengar S, Ivanov AV, Jin VX, Rauscher FJ III \& Farnham PJ 2011 Functional analysis of KAP1 genomic recruitment. Molecular and Cellular Biology 31 1833-1847. (doi:10.1128/MCB.01331-10)

Jeong YS, Yeo S, Park JS, Koo DB, Chang WK, Lee KK \& Kang YK 2007 DNA methylation state is preserved in the sperm-derived pronucleus of the pig zygote. International Journal of Developmental Biology 51 707-714. (doi:10.1387/ijdb.072450yj)

Kaneda M, Okano M, Hata K, Sado T, Tsujimoto N, Li E \& Sasaki H 2004 Essential role for de novo DNA methyltransferase Dnmt3a in paternal and maternal imprinting. Nature 429 900-903. (doi:10.1038/ nature02633)

Kato Y, Kaneda M, Hata K, Kumaki K, Hisano M, Kohara Y, Okano M, Li E, Nozaki M \& Sasaki H 2007 Role of the Dnmt3 family in de novo methylation of imprinted and repetitive sequences during male germ cell development in the mouse. Human Molecular Genetics 16 2272-2280. (doi:10.1093/hmg/ddm179)

Kidder GM \& Winterhager E 2001 Intercellular communication in preimplantation development: the role of gap junctions. Frontiers in Bioscience 6 D731-D736. (doi:10.2741/Kidder)

Kirchhof N, Carnwath JW, Lemme E, Anastassiadis K, Scholer H \& Niemann H 2000 Expression pattern of Oct-4 in preimplantation embryos of different species. Biology of Reproduction 63 1698-1705. (doi:10.1095/biolreprod63.6.1698)

Kishikawa S, Murata T, Ugai H, Yamazaki T \& Yokoyama KK 2003 Control elements of Dnmt1 gene are regulated in cell-cycle dependent manner. Nucleic Acids Research. Supplement (2001) 3 307-308. (doi:10.1093/ nass/3.1.307)

Kohli RM \& Zhang Y 2013 TET enzymes, TDG and the dynamics of DNA demethylation. Nature 502 472-479. (doi:10.1038/nature12750)

Kouzarides T 2007 Chromatin modifications and their function. Cell 128 693-705. (doi:10.1016/j.cell.2007.02.005)

Lane N, Dean W, Erhardt S, Hajkova P, Surani A, Walter J \& Reik W 2003 Resistance of IAPs to methylation reprogramming may provide a mechanism for epigenetic inheritance in the mouse. Genesis 35 88-93. (doi:10.1002/gene.10168)

Latham KE, Solter D \& Schultz RM 1991 Activation of a two-cell stagespecific gene following transfer of heterologous nuclei into enucleated mouse embryos. Molecular Reproduction and Development 30 182-186. (doi:10.1002/mrd.1080300303)

Leonhardt H, Page AW, Weier HU \& Bestor TH 1992 A targeting sequence directs DNA methyltransferase to sites of DNA replication in mammalian nuclei. Cell 71 865-873. (doi:10.1016/0092-8674(92)90561-P)

Lepikhov K \& Walter J 2004 Differential dynamics of histone H3 methylation at positions $\mathrm{K} 4$ and $\mathrm{K} 9$ in the mouse zygote. BMC Developmental Biology 4 12. (doi:10.1186/1471-213X-4-12)

Leung D, Du T, Wagner U, Xie W, Lee AY, Goyal P, Li Y, Szulwach KE, Jin P, Lorincz MC et al. 2014 Regulation of DNA methylation turnover at LTR retrotransposons and imprinted loci by the histone methyltransferase Setdb1. PNAS 111 6690-6695. (doi:10.1073/pnas. 1322273111) 
Li E, Bestor TH \& Jaenisch R 1992 Targeted mutation of the DNA methyltransferase gene results in embryonic lethality. Cell 69 915-926. (doi:10.1016/0092-8674(92)90611-F)

Li X, Ito M, Zhou F, Youngson N, Zuo X, Leder P \& Ferguson-Smith AC 2008 A maternal-zygotic effect gene, Zfp57, maintains both maternal and paternal imprints. Developmental Cell 15 547-557. (doi:10.1016/ j.devcel.2008.08.014)

Ma P \& Schultz RM 2008 Histone deacetylase 1 (HDAC1) regulates histone acetylation, development, and gene expression in preimplantation mouse embryos. Developmental Biology 319 110-120. (doi:10.1016/ j.ydbio.2008.04.011)

Majumder S \& DePamphilis ML 1994 Requirements for DNA transcription and replication at the beginning of mouse development. Journal of Cellular Biochemistry 55 59-68. (doi:10.1002/jcb.240550107)

Maunakea AK, Nagarajan RP, Bilenky M, Ballinger TJ, D'Souza C, Fouse SD, Johnson BE, Hong C, Nielsen C, Zhao Y et al. 2010 Conserved role of intragenic DNA methylation in regulating alternative promoters. Nature 466 253-257. (doi:10.1038/nature09165)

Mayer W, Niveleau A, Walter J, Fundele R \& Haaf T 2000 Demethylation of the zygotic paternal genome. Nature 403 501-502. (doi:10.1038/ 35000656)

McDonel P, Costello I \& Hendrich B 2009 Keeping things quiet: roles of NuRD and Sin3 co-repressor complexes during mammalian development. International Journal of Biochemistry \& Cell Biology 41 108-116. (doi:10.1016/j.biocel.2008.07.022)

Mertineit C, Yoder JA, Taketo T, Laird DW, Trasler JM \& Bestor TH 1998 Sex-specific exons control DNA methyltransferase in mammalian germ cells. Development 125 889-897.

Messerschmidt DM, de Vries W, Ito M, Solter D, Ferguson-Smith A \& Knowles BB 2012 Trim28 is required for epigenetic stability during mouse oocyte to embryo transition. Science 335 1499-1502. (doi:10. 1126/science.1216154)

Nakamura T, Arai $\mathrm{Y}$, Umehara H, Masuhara $\mathrm{M}$, Kimura T, Taniguchi $\mathbf{H}$, Sekimoto T, Ikawa M, Yoneda Y, Okabe M et al. 2007 PGC7/Stella protects against DNA demethylation in early embryogenesis. Nature Cell Biology 9 64-71. (doi:10.1038/ncb1519)

Nakamura T, Liu YJ, Nakashima H, Umehara H, Inoue K, Matoba S, Tachibana M, Ogura A, Shinkai Y \& Nakano T 2012 PGC7 binds histone $\mathrm{H} 3 \mathrm{~K} 9 \mathrm{me} 2$ to protect against conversion of $5 \mathrm{mC}$ to $5 \mathrm{hmC}$ in early embryos. Nature 486 415-419. (doi:10.1038/nature11093)

Nichols J \& Gardner RL 1984 Heterogeneous differentiation of external cells in individual isolated early mouse inner cell masses in culture. Journal of Embryology and Experimental Morphology 80 225-240.

Nothias JY, Majumder S, Kaneko KJ \& DePamphilis ML 1995 Regulation of gene expression at the beginning of mammalian development. Journal of Biological Chemistry 270 22077-22080. (doi:10.1074/jbc.270.38. 22077)

Oda H, Okamoto I, Murphy N, Chu J, Price SM, Shen MM, TorresPadilla ME, Heard E \& Reinberg D 2009 Monomethylation of histone $\mathrm{H} 4$-lysine 20 is involved in chromosome structure and stability and is essential for mouse development. Molecular and Cellular Biology 29 2278-2295. (doi:10.1128/MCB.01768-08)

Okano M, Bell DW, Haber DA \& Li E 1999 DNA methyltransferases Dnmt3a and Dnmt3b are essential for de novo methylation and mammalian development. Cell 99 247-257. (doi:10.1016/S0092-8674(00)81656-6)

Ooga M, Suzuki MG \& Aoki F 2013 Involvement of DOT1L in the remodeling of heterochromatin configuration during early preimplantation development in mice. Biology of Reproduction 89 145. (doi:10. 1095/biolreprod.113.113258)

Ooga M, Suzuki MG \& Aoki F 2015 Involvement of histone H2B monoubiquitination in the regulation of mouse preimplantation development. Journal of Reproduction and Development 61 179-184.

Oswald J, Engemann S, Lane N, Mayer W, Olek A, Fundele R, Dean W, Reik W \& Walter J 2000 Active demethylation of the paternal genome in the mouse zygote. Current Biology 10 475-478. (doi:10.1016/S09609822(00)00448-6)

Park JS, Lee D, Cho S, Shin ST \& Kang YK 2010 Active loss of DNA methylation in two-cell stage goat embryos. International Journal of Developmental Biology 54 1323-1328. (doi:10.1387/ijdb.092973jp)

Paul S \& Knott JG 2014 Epigenetic control of cell fate in mouse blastocysts: the role of covalent histone modifications and chromatin remodeling. Molecular Reproduction and Development 81 171-182. (doi:10.1002/mrd.22219)
Peat JR, Dean W, Clark SJ, Krueger F, Smallwood SA, Ficz G, Kim JK, Marioni JC, Hore TA \& Reik W 2014 Genome-wide bisulfite sequencing in zygotes identifies demethylation targets and maps the contribution of TET3 oxidation. Cell Reports 9 1990-2000. (doi:10.1016/j.celrep.2014.11.034)

Pedersen RA, Wu K \& Balakier H 1986 Origin of the inner cell mass in mouse embryos: cell lineage analysis by microinjection. Developmental Biology 117 581-595. (doi:10.1016/0012-1606(86)90327-1)

Pesce M \& Scholer HR 2001 Oct-4: gatekeeper in the beginnings of mammalian development. Stem Cells 19 271-278. (doi:10.1634/ stemcells.19-4-271)

Posfai E, Kunzmann R, Brochard V, Salvaing J, Cabuy E, Roloff TC, Liu Z, Tardat M, van Lohuizen M, Vidal M et al. 2012 Polycomb function during oogenesis is required for mouse embryonic development. Genes and Development 26 920-932. (doi:10.1101/gad.188094.112)

Quenneville S, Verde G, Corsinotti A, Kapopoulou A, Jakobsson J, Offner S, Baglivo I, Pedone PV, Grimaldi G, Riccio A et al. 2011 In embryonic stem cells, ZFP57/KAP1 recognize a methylated hexanucleotide to affect chromatin and DNA methylation of imprinting control regions. Molecular Cell 44 361-372. (doi:10.1016/j.molcel.2011.08.032)

Reis e Silva AR, Bruno C, Fleurot R, Daniel N, Archilla C, Peynot N, Lucci CM, Beaujean N \& Duranthon V 2012 Alteration of DNA demethylation dynamics by in vitro culture conditions in rabbit preimplantation embryos. Epigenetics 7 440-446. (doi:10.4161/epi.19563)

Ribeiro-Mason K, Boulesteix C, Brochard V, Aguirre-Lavin T, Salvaing J, Fleurot R, Adenot P, Maalouf WE \& Beaujean N 2012 Nuclear dynamics of histone $\mathrm{H} 3$ trimethylated on lysine 9 and/or phosphorylated on serine 10 in mouse cloned embryos as new markers of reprogramming? Cellular Reprogramming 14 283-294. (doi:10.1089/cell.2011.0071)

Rouleau J, Tanigawa G \& Szyf M 1992 The mouse DNA methyltransferase 5 '-region. A unique housekeeping gene promoter. Journal of Biological Chemistry 267 7368-7377.

Rugg-Gunn PJ, Cox BJ, Ralston A \& Rossant J 2010 Distinct histone modifications in stem cell lines and tissue lineages from the early mouse embryo. PNAS 107 10783-10790. (doi:10.1073/pnas.0914507107)

Saha B, Home P, Ray S, Larson M, Paul A, Rajendran G, Behr B \& Paul S 2013 EED and KDM6B coordinate the first mammalian cell lineage commitment to ensure embryo implantation. Molecular and Cellular Biology 33 2691-2705. (doi:10.1128/MCB.00069-13)

Saitou M, Barton SC \& Surani MA 2002 A molecular programme for the specification of germ cell fate in mice. Nature 418 293-300. (doi:10. 1038/nature00927)

Sakaue M, Ohta H, Kumaki Y, Oda M, Sakaide Y, Matsuoka C, Yamagiwa A, Niwa H, Wakayama T \& Okano M 2010 DNA methylation is dispensable for the growth and survival of the extraembryonic lineages. Current Biology 20 1452-1457. (doi:10.1016/j.cub.2010.06.050)

Santenard A, Ziegler-Birling C, Koch M, Tora L, Bannister AJ \& TorresPadilla ME 2010 Heterochromatin formation in the mouse embryo requires critical residues of the histone variant $\mathrm{H} 3.3$. Nature Cell Biology 12 853-862. (doi:10.1038/ncb2089)

Santos F, Hendrich B, Reik W \& Dean W 2002 Dynamic reprogramming of DNA methylation in the early mouse embryo. Developmental Biology 241 172-182. (doi:10.1006/dbio.2001.0501)

Santos F, Peters AH, Otte AP, Reik W \& Dean W 2005 Dynamic chromatin modifications characterise the first cell cycle in mouse embryos. Developmental Biology 280 225-236. (doi:10.1016/j.ydbio.2005.01.025)

Sarmento OF, Digilio LC, Wang Y, Perlin J, Herr JC, Allis CD \& Coonrod SA 2004 Dynamic alterations of specific histone modifications during early murine development. Journal of Cell Science 117 4449-4459. (doi:10. 1242/jcs.01328)

Sato M, Kimura T, Kurokawa K, Fujita Y, Abe K, Masuhara M, Yasunaga T, Ryo A, Yamamoto M \& Nakano T 2002 Identification of PGC7, a new gene expressed specifically in preimplantation embryos and germ cells. Mechanisms of Development 113 91-94. (doi:10.1016/S09254773(02)00002-3)

Saxonov S, Berg P \& Brutlag DL 2006 A genome-wide analysis of CpG dinucleotides in the human genome distinguishes two distinct classes of promoters. PNAS 103 1412-1417. (doi:10.1073/pnas.0510310103)

Schrode N, Xenopoulos P, Piliszek A, Frankenberg S, Plusa B \& Hadjantonakis AK 2013 Anatomy of a blastocyst: cell behaviors driving cell fate choice and morphogenesis in the early mouse embryo. Genesis 51 219-233. (doi:10.1002/dvg.22368) 
Schultz RM 2002 The molecular foundations of the maternal to zygotic transition in the preimplantation embryo. Human Reproduction Update 8 323-331. (doi:10.1093/humupd/8.4.323)

Schultz GA, Hahnel A, Arcellana-Panlilio M, Wang L, Goubau S, Watson A \& Harvey M 1993 Expression of IGF ligand and receptor genes during preimplantation mammalian development. Molecular Reproduction and Development 35 414-420. (doi:10.1002/mrd.1080350416)

Shao GB, Ding HM \& Gong AH 2008 Role of histone methylation in zygotic genome activation in the preimplantation mouse embryo. In Vitro Cellular \& Developmental Biology. Animal 44 115-120. (doi:10.1007/ s11626-008-9082-4)

Shen L, Inoue A, He J, Liu Y, Lu F \& Zhang Y 2014 Tet3 and DNA replication mediate demethylation of both the maternal and paternal genomes in mouse zygotes. Cell Stem Cell 15 459-470. (doi:10.1016/j.stem.2014. 09.002)

Sleutels F, Tjon G, Ludwig T \& Barlow DP 2003 Imprinted silencing of Slc22a2 and Slc22a3 does not need transcriptional overlap between Igf $2 r$ and Air. EMBO Journal 22 3696-3704. (doi:10.1093/emboj/cdg341)

Smallwood SA, Tomizawa S, Krueger F, Ruf N, Carli N, Segonds-Pichon A, Sato S, Hata K, Andrews SR \& Kelsey G 2011 Dynamic CpG island methylation landscape in oocytes and preimplantation embryos. Nature Genetics 43 811-814. (doi:10.1038/ng.864)

Smith ZD, Chan MM, Mikkelsen TS, Gu H, Gnirke A, Regev A \& Meissner A 2012 A unique regulatory phase of DNA methylation in the early mammalian embryo. Nature 484 339-344. (doi:10.1038/nature10960)

Stein P, Worrad DM, Belyaev ND, Turner BM \& Schultz RM 1997 Stagedependent redistributions of acetylated histones in nuclei of the early preimplantation mouse embryo. Molecular Reproduction and Development 47 421-429. (doi:10.1002/(SICI)1098-2795(199708) 47:4<421::AID-MRD8>3.0.CO;2-M)

Strahl BD \& Allis CD 2000 The language of covalent histone modifications. Nature 403 41-45. (doi:10.1038/47412)

Sui X, Price C, Li Z \& Chen J 2012 Crosstalk between DNA and histones: Tet's new role in embryonic stem cells. Current Genomics 13 603-608. (doi:10.2174/138920212803759730)

Suo L, Meng Q, Pei Y, Fu X, Wang Y, Bunch TD \& Zhu S 2010 Effect of cryopreservation on acetylation patterns of lysine 12 of histone $\mathrm{H} 4$ (acH4K12) in mouse oocytes and zygotes. Journal of Assisted Reproduction and Genetics 27 735-741. (doi:10.1007/s10815-0109469-5)

Takada S, Paulsen M, Tevendale M, Tsai CE, Kelsey G, Cattanach BM \& Ferguson-Smith AC 2002 Epigenetic analysis of the Dlk1-Gtl2 imprinted domain on mouse chromosome 12: implications for imprinting control from comparison with Igf2-H19. Human Molecular Genetics 11 77-86. (doi:10.1093/hmg/11.1.77)

Tan M, Luo H, Lee S, Jin F, Yang JS, Montellier E, Buchou T, Cheng Z, Rousseaux S, Rajagopal N et al. 2011 Identification of 67 histone marks and histone lysine crotonylation as a new type of histone modification. Cell 146 1016-1028. (doi:10.1016/j.cell.2011.08.008)

Tanaka M, Hennebold JD, Macfarlane J \& Adashi EY 2001 A mammalian oocyte-specific linker histone gene H1oo: homology with the genes for the oocyte-specific cleavage stage histone $(\mathrm{cs}-\mathrm{H} 1)$ of sea urchin and the B4/H1M histone of the frog. Development 128 655-664.

Torres-Padilla ME, Parfitt DE, Kouzarides T \& Zernicka-Goetz M 2007 Histone arginine methylation regulates pluripotency in the early mouse embryo. Nature 445 214-218. (doi:10.1038/nature05458)

Tsukada Y, Fang J, Erdjument-Bromage $\mathbf{H}$, Warren ME, Borchers $\mathbf{C H}$, Tempst P \& Zhang Y 2006 Histone demethylation by a family of JmjC domain-containing proteins. Nature 439 811-816. (doi:10.1038/ nature04433)

VerMilyea MD, O'Neill LP \& Turner BM 2009 Transcription-independent heritability of induced histone modifications in the mouse preimplantation embryo. PLoS ONE 4 e6086. (doi:10.1371/journal.pone.0006086)

Wang J, Zhang M, Zhang Y, Kou Z, Han Z, Chen DY, Sun QY \& Gao S 2010 The histone demethylase JMJD2C is stage-specifically expressed in preimplantation mouse embryos and is required for embryonic development. Biology of Reproduction 82 105-111. (doi:10.1095/ biolreprod.109.078055)
Wang J, Xie G, Singh M, Ghanbarian AT, Rasko T, Szvetnik A, Cai H, Besser D, Prigione A, Fuchs NV et al. 2014 Primate-specific endogenous retrovirus-driven transcription defines naive-like stem cells. Nature $\mathbf{5 1 6}$ 405-409. (doi:10.1038/nature13804)

Watanabe D, Suetake I, Tada T \& Tajima S 2002 Stage- and cell-specific expression of Dnmt3a and Dnmt3b during embryogenesis. Mechanisms of Development 118 187-190. (doi:10.1016/S0925-4773(02)00242-3)

Watson AJ, Damsky CH \& Kidder GM 1990 Differentiation of an epithelium: factors affecting the polarized distribution of $\mathrm{Na}+, \mathrm{K}(+)$ ATPase in mouse trophectoderm. Developmental Biology 141 104-114. (doi:10.1016/0012-1606(90)90105-R)

Wongtawan T, Taylor JE, Lawson KA, Wilmut I \& Pennings S 2011 Histone $\mathrm{H} 4 \mathrm{~K} 20 \mathrm{me} 3$ and $\mathrm{HP} 1 \alpha$ are late heterochromatin markers in development, but present in undifferentiated embryonic stem cells. Journal of Cell Science 124 1878-1890. (doi:10.1242/jcs.080721)

Wossidlo M, Arand J, Sebastiano V, Lepikhov K, Boiani M, Reinhardt R, Scholer H \& Walter J 2010 Dynamic link of DNA demethylation, DNA strand breaks and repair in mouse zygotes. EMBO Journal 29 1877-1888. (doi:10.1038/emboj.2010.80)

Wossidlo M, Nakamura T, Lepikhov K, Marques CJ, Zakhartchenko V, Boiani M, Arand J, Nakano T, Reik W \& Walter J 2011 5-Hydroxymethylcytosine in the mammalian zygote is linked with epigenetic reprogramming. Nature Communications 2 241. (doi:10.1038/ncomms1240)

Wu FR, Liu Y, Shang MB, Yang XX, Ding B, Gao JG, Wang R \& Li WY 2012 Differences in $\mathrm{H} 3 \mathrm{~K} 4$ trimethylation in in vivo and in vitro fertilization mouse preimplantation embryos. Genetics and Molecular Research 11 1099-1108. (doi:10.4238/2012.April.27.9)

Yamanaka Y, Ralston A, Stephenson RO \& Rossant J 2006 Cell and molecular regulation of the mouse blastocyst. Developmental Dynamics 235 2301-2314. (doi:10.1002/dvdy.20844)

Yan L, Yang M, Guo H, Yang L, Wu J, Li R, Liu P, Lian Y, Zheng X, Yan J et al. 2013 Single-cell RNA-Seq profiling of human preimplantation embryos and embryonic stem cells. Nature Structural \& Molecular Biology 20 1131-1139. (doi:10.1038/nsmb.2660)

Yeap LS, Hayashi K \& Surani MA 2009 ERG-associated protein with SET domain (ESET)-Oct4 interaction regulates pluripotency and represses the trophectoderm lineage. Epigenetics \& Chromatin 2 12. (doi:10.1186/ 1756-8935-2-12)

Young LE \& Beaujean N 2004 DNA methylation in the preimplantation embryo: the differing stories of the mouse and sheep. Animal Reproduction Science 82-83 61-78.

Zaitseva I, Zaitsev S, Alenina N, Bader M \& Krivokharchenko A 2007 Dynamics of DNA-demethylation in early mouse and rat embryos developed in vivo and in vitro. Molecular Reproduction and Development 74 1255-1261. (doi:10.1002/mrd.20704)

Zhang K, Haversat JM \& Mager J 2013a CTR9/PAF1c regulates molecular lineage identity, histone $\mathrm{H} 3 \mathrm{~K} 36$ trimethylation and genomic imprinting during preimplantation development. Developmental Biology 383 15-27. (doi:10.1016/j.ydbio.2013.09.005)

Zhang K, Dai X, Wallingford MC \& Mager J 2013b Depletion of Suds3 reveals an essential role in early lineage specification. Developmental Biology 373 359-372. (doi:10.1016/j.ydbio.2012.10.026)

Zhou L, Wang P, Zhang J, Heng BC \& Tong GQ 2015 ING2 (inhibitor of growth protein-2) plays a crucial role in preimplantation development. Zygote (In press). (doi:10.1017/S0967199414000768)

Zuo X, Sheng J, Lau HT, McDonald CM, Andrade M, Cullen DE, Bell FT, lacovino M, Kyba M, Xu G et al. 2012 Zinc finger protein ZFP57 requires its co-factor to recruit DNA methyltransferases and maintains DNA methylation imprint in embryonic stem cells via its transcriptional repression domain. Journal of Biological Chemistry 287 2107-2118. (doi:10.1074/jbc.M111.322644)

Received 17 April 2015

First decision 11 May 2015

Revised manuscript received 26 May 2015

Accepted 1 June 2015 